\title{
Staphylococcus in Raw Cow's Milk from Maroua (Cameroon), Determination of Their Resistance Level to Antibiotics
}

\section{Justine Maïwore ${ }^{1 *}$, Daouda Youssouf ${ }^{1}$, Alhadji Toudjani Amadou ${ }^{1}$, Martin-Paul Baane ${ }^{2}$, Léopold Tatsadjieu Ngoune $^{3}$ and Et Didier Montet $^{4}$}

${ }^{1}$ Department of Life and Earth Sciences, University of Maroua, Higher Teachers' Training College, Maroua, Cameroon

${ }^{2}$ Laboratory of the hospital of National Social Insurance Fund (NSIF), Maroua, Cameroon

${ }^{3}$ Department of Food Engineering and Quality Control, University Institute of technology, University of Ngaoundere, Ngaoundere, Adamaoua, Cameroon ${ }^{4}$ UMR 95 Quali Sud/Cirad/University of Montpellier, TAB-95/16, 73 rue J-F Breton, Montpellier Cedex, France

*Corresponding Author: Justine Maïwore, Department of Life and Earth Sciences, University of Maroua, Higher Teachers' Training College, Maroua, Cameroon.
Received: February 24, 2020

Published: March 06, 2020

(C) All rights are reserved by Justine Maïwore., et al.

\begin{abstract}
Raw cow's milk produced locally is a popular commodity but, its quality is a hindrance for the consumers. The objective of this study was firstly to identify the Staphylococcus present in raw cow's milk collected in Maroua (Cameroon) and, secondly to assess their level of resistance to antibiotics. Physico-chemical analyses based on the temperature, $\mathrm{pH}$ and titrable acidity were carried out. For the microbial analysis, the plating method was used to isolate and, the count of the total mesophilic aerobic flora (TMAF) and Staphylococcus was done. After identification, the resistance of Staphylococcus to antibiotics was assessed. The results obtained revealed that the temperature value was between $34.3 \pm 0.282$ and $36 \pm 0.212^{\circ} \mathrm{C}$; the pH between $5.18 \pm 0.32$ and $5.80 \pm 0.2$ and the density between $1.025 \pm 0.0007$ and $1.030 \pm 0.0021$. Microbiological analyses revealed that TMAF ranged from $(9 \pm 0.9) 10^{3}$ to $(7.2 \pm$ $0.9) 10^{9} \mathrm{CFU} / \mathrm{mL}$ while the abundance of Staphylococcus ranged from (1.2 \pm 0.3$) 10^{3}$ to $(1.03 \pm 0.08) 10^{4} \mathrm{CFU} / \mathrm{mL}$. Nineteen (19) species of Staphylococcus were identified with a predominance of the aureus specie $(68.62 \%)$. The antibiogram revealed $95 \%$ resistance to $\beta$-lactam, 78\% to Macrolides, $42 \%$ to Glycopeptides, $16 \%$ to Quinolones, 5\% to Aminosides and Cotrimoxazole and $0 \%$ to Chloramphenicol. Raw milk from Maroua has a high rate of Staphylococcus antibiotic-resistant.
\end{abstract}

Keywords: Raw Milk; Staphylococcus; Antibiotics; Resistance; Maroua

\section{Abbreviations}

FAO: Food And Agriculture Organization; N: North; E: East; ALT: Altitude; Ph: Potential Of Hydrogene; TMAF: Total Mesophilic Aerobic Flora; CFU: Colony Forming Unit; S1: Site1; T: Temperature; AFNOR: Association Française De Normalisation; S: Sensitive; R:
Resistant; I: Intermédiaire; B-Lac: B-Lactam; GLYC: Glycopeptides; Amin: Aminosides; MACR: Macrolides; Quin: Quinolones; CHLO: Chloramphenicol; COTR: Cotrimoxazole; NITR: Nitrofurantoine; Fus A: Fusidic A; DAPT: Daptomycin; RIFA: Rifampicin; ANOVA: Analysis Of Variance 


\section{Introduction}

Milk is a basic food in the human diet with great value thanks to its composition in nutrients like proteins, lipids, carbohydrates and calcium. It also plays an important role in food security for many people [1-3]. Nowadays, the needs for milk are more and more important since this product can be consumed in the fresh state, but also in pasteurized form, sterilized or transformed into derived products such as: fresh cheese, butter and milk fermented [4]. However, milk constitutes an excellent substrate for the proliferation of pathogenic germs thus, an important source of microbial infection for the consumers without pasteurization $[1,5,6]$. The milk contamination may be due to intrinsic and extrinsic factors. It can come from poor hygiene and health status of the cow, mastitis prevalence, production environment, and milking room and milk conserving practices in dairy farm [6-8].

In Maroua, raw milk is produced by cows raised in poorly maintained pens and where basic hygiene practices are not respected. These conditions generally affect the physico-chemical and microbiological quality of milk [9]. The milks produced in these conditions contain several opportunistic and potentially pathogenic germs such as Salmonella, Streptococcus and Staphylococcus [10]. It was shown that the microbiological quality of dairy products reflects good hygienic practices during the dairy milking process; raw milk contamination could occur in diseased or infected cows with environmental bacteria [11].

Microbiological analyzes of some samples of raw and fermented milks in Maroua have revealed that the majority were not of good quality $[9,12]$. These milks have a high level of opportunistic and pathogen bacteria, among which there is Staphylococcus and particularly the species aureus. In humans Staphylococcus aureus is responsible of food poisoning, skin diseases and in some cases of sepsis which can cause death $[13,14]$. Several strains of Staphylococcus show a high level of resistance to antibiotics $[15,16]$. Information on the antibiotic resistance level of Staphylococcus present in food could contribute greatly to the control of transmission's chain in bacterial resistance to humans. The objective of this study is to identify staphylococci in raw milks from Maroua (Cameroon) and evaluate their resistance to antibiotics.

\section{Materials and Methods}

Study zone and sampling

Raw milk samples were collected from farmers during milking time (between 5 a.m. and 6 a.m.) in five different quarters of the city of Maroua in the Far North Region of Cameroon: Domayo, Hardé 1, Missingueleo, Harde 2 (Table 1). This region have a favorable environment for the development of livestock farming, milk and its products are thus an integral part of the diet. The milk produced by cows is used for domestic consumption and the left over is sometimes sold for the needs of the whole family. The milk samples were from manual milking in the morning before the animals leave the sheepfold. A total, 30 raw milk samples were collected from five sedentary farmers in the city of Maroua from January to March 2018. Six samples by producers were collected: for physicochemical analyzes, 4 samples were used to determine the temperature and the $\mathrm{pH}$ of the milk at the outlet of the udder and to measure the density of milk in the laboratory; 2 other samples were used for microbiological analysis in laboratory. The milk samples collected were collected in sterile $500 \mathrm{ml}$ glass bottles, labeled and then sent to the laboratory at $4^{\circ} \mathrm{C}$ for further analysis in a cooler containing carboglaces.

\begin{tabular}{|l|c|c|}
\hline Sites & Samples & Geographic coordinates \\
\hline Kakataré & 6 & N 10.59980 \\
& & E 014.32036 \\
Hardé 1 & 6 & N 10.58792 \\
& & E 014. 32609 \\
\hline Domayo & 6 & ALT $: 399 \mathrm{~m}$ \\
\hline \multirow{2}{*}{ Missinguelow } & 6 & E 10.35155 \\
& & ALT $: 400 \mathrm{~m}$ \\
\hline Hardé 2 & & N 10.60763 \\
& 6 & E 014. 29580 \\
& & N 10.58790 \\
& & E 014. 32616 \\
& & ALT $: 388 \mathrm{~m}$ \\
\hline
\end{tabular}

Table 1: Sampling sites.

Physico-chemical analysis

Immediately after milking, the temperature and $\mathrm{pH}$ at the outlet of the cow's udder were measured in situ using a $\mathrm{pH}$ meter (HANNA, HI9124) and a digital electronic thermometer (Matter Flo, 250513). Electrodes of these devices were immersed in $50 \mathrm{ml}$ of raw milk and the values increased after stabilization. This opera- 
tion was repeated three times. The density was measured using the technique described by [17]. The samples were homogenized and then poured into a $500 \mathrm{ml}$ test tube, avoiding the formation of foam and taking care to fill it. The thermolactodensimeter (Gerber) was then gently immersed in the milk, holding it in its descent to near its equilibrium position and taking care to let it float freely. A slight rotational movement was then administered to the thermolactodensimeter. The gross density and the temperature were then read. When the temperature was different from $20^{\circ} \mathrm{C}$, corrections were made by adding 0.0002 per degree if the temperature is above $20^{\circ} \mathrm{C}$ or by reducing 0.0002 on the gross density if it is lower than the standard temperature.

\section{Microbiological analysis}

Samples preparation

The microbiological methods used are those described by [18]. After homogenization of the raw milk samples using a vortex, series of decimal dilutions were carried out by adding $1 \mathrm{~mL}$ of each pure sample to a test tube containing $9 \mathrm{ml}$ of peptone water (Roseto Abruzzi, Italy). This operation was repeated ten times in test tubes until the tenth dilution was obtained. The dilutions were homogenized and then added to culture media based on the desired microorganism.

Total mesophilic aerobic flora (TMAF) and Staphylococcus counts

For the enumeration of the total mesophilic aerobic flora (TMAF), $100 \mu \mathrm{l}$ of each dilution was inoculated on the sterilized PCA agar (Plate Count Agar, Roseto Abruzzi, Italy). After spreading the inoculum, the petri dishes were incubated at $30^{\circ} \mathrm{C}$ for 72 hours. The colonies obtained were counted and the results were given in Colony-forming Unit per ml of milk (CFU/ mL) [19].

For the enumeration of Staphylococcus, $100 \mu \mathrm{L}$ of each dilution was inoculated on the surface on the sterile Chapman agar (Humeau, France). The inoculated petri dishes were then incubated at $37^{\circ} \mathrm{C}$ for 24 hours.

\section{Characterization and identification of Staphylococcus}

The colonies obtained were characterized by several tests. First, Gram staining was carried out on the different colonies and only the Gram + coccus arranged in clusters were retained. The catalase test was also carried out on the colonies obtained. The search for DNase (Deoxyribonuclease) was done by cultivating a presumptive Staphylococcus on the DNase agar (Difco, Detroit), the petri dishes were incubated at $37^{\circ} \mathrm{C}$ for 24 hours. After this the dishes were flooded with hydrochloric acid and the excess liquid is poured out. The presence of a clear halo around the colony shows the activity of DNAse and the bacteria is categorized Staphylococcus aureus. These tests permitted to differentiate Staphylococcus aureus (Coccus Gram +, Catalase + and DNase +) from the other Staphylococcus (Coccus Gram +, Catalase + and DNase-) [20]. DNAse negative bacteria were identified as Staphylococcus spp.

\section{Antibiogram and resistance percentage of Staphylococcus}

The disk diffusion method was used to confirm the susceptibility of Staphylococcus to antibiotics Standardized disks, according to the recommendations of the European antibiogram committee [21]. In this method, the isolated Staphylococcus was suspended and standardized through a turbidity test. An inoculum of 0.5 opacity on the Mc Farland scale was made in a test tube containing distilled water. The previous suspension was then inoculated onto the solidified Mueller-Hinton (Biokar, France) agar, and the antibiotictreated paper was tapped on the inoculated plate. The dishes were incubated at $35{ }^{\circ} \mathrm{C}$ for 24 hours to allow the discs containing antibiotics to diffuse through the solidified agar resulting in the formation of an inhibition zone. After this, the size of the inhibition zone formed around the paper disc was then measured and then interpreted according to the method of $[21,22]$. The inhibition size zone corresponds to the concentration of the antibiotic. The resistance percentages of Staphylococcus against different families of antibiotics were then calculated. The antibiotics used are listed in table 2.

\section{Statistical analysis}

The variance of the different repetitions was obtained by using Microsoft Office Excel 2007 software. On Statgraphics Centurion 17.1.06. Software, ANOVA with one factor, followed by the Duncan test was performed to compare the different samples of raw milk from each site. 


\begin{tabular}{|c|c|c|c|}
\hline Family & Antibiotic & Load & Symbol \\
\hline \multirow[t]{6}{*}{ Beta-lactams } & Penicillin G & 10UI & $\mathrm{P}$ \\
\hline & Oxacillin & $5 \mu \mathrm{g}$ & oX \\
\hline & Cefotaxime & $30 / 10 \mu \mathrm{g}$ & СTX \\
\hline & Meropenem & $10 \mu \mathrm{g}$ & MRP \\
\hline & Daptomycin & $30 \mu \mathrm{g}$ & DAP \\
\hline & Moxalactam & $30 \mu \mathrm{g}$ & MX \\
\hline \multirow[t]{2}{*}{ Glycopeptides } & Teicoplanin & $30 \mu \mathrm{g}$ & TEI \\
\hline & Vancomycin & $10 \mu \mathrm{g}$ & VA \\
\hline \multirow[t]{5}{*}{ Aminosides } & Gentamycin & $10 \mu \mathrm{g}$ & GEN \\
\hline & Tobramycin & $30 \mu \mathrm{g}$ & TOB \\
\hline & Amikacin & $30 \mu \mathrm{g}$ & $\mathrm{AK}$ \\
\hline & Netilmycin & $30 \mu \mathrm{g}$ & NET \\
\hline & Isepamicin & $30 \mu \mathrm{g}$ & ISE \\
\hline \multirow{6}{*}{$\begin{array}{l}\text { Macrolides and } \\
\text { related }\end{array}$} & Erythromycin & $30 \mu \mathrm{g}$ & $\mathrm{E}$ \\
\hline & Lincomycin & $10 \mu \mathrm{g}$ & $\mathrm{L}$ \\
\hline & Clindamycin & $2 \mathrm{UI}$ & $\mathrm{CD}$ \\
\hline & Spiramycin & $30 \mu \mathrm{g}$ & SPR \\
\hline & Pristinamycin & $15 \mathrm{UI}$ & $\mathrm{RP}$ \\
\hline & Telithromycin & $15 \mu \mathrm{g}$ & TEL \\
\hline \multirow{2}{*}{$\begin{array}{l}\text { Quinolones and Fluo- } \\
\text { roquinolones }\end{array}$} & Ofloxacin & $5 \mu \mathrm{g}$ & $\mathrm{OF}$ \\
\hline & Levofloxacin & $5 \mu \mathrm{g}$ & LEV \\
\hline Phenicols & Chloramphénicol & $30 \mu \mathrm{g}$ & $\mathrm{C}$ \\
\hline Sulfamides & Cotrimoxazol & $25 \mu \mathrm{g}$ & COT \\
\hline Nitrated products & Nitrofurantoin & $100 \mu \mathrm{g}$ & NIT \\
\hline Others & Rifampicin & $30 \mu \mathrm{g}$ & RIF \\
\hline
\end{tabular}

Table 2: Antibiotics used for Staphylococcus antibiograms.

\section{Results and Discussion}

Physical quality of raw milk

The physicochemical characteristics $(\mathrm{pH}$, temperature and density) of raw milk analyzed are presented in the table 3 . The $\mathrm{pH}$ values vary between $5.18 \pm 0.32$ (S2) and $5.80 \pm 0.2$ (S4) with $100 \%$ of the samples that do not respect the standards value. The temperature of the milk measured directly at the outlet of the udder is between $34.3 \pm 0.282{ }^{\circ} \mathrm{C}$ (S2) and $36 \pm 0.212^{\circ} \mathrm{C}$ (S1). The density ranges from $1.025 \pm 0.0007$ (S2) to $1.030 \pm 0.0021$ (S5) with $80 \%$ of raw milk samples having a density below the standard $(1.028<$ normal density $>1.033$. There was a significant difference between the samples for the three parameters studied $(\mathrm{P}>0.05)$.

\begin{tabular}{|l|c|c|c|}
\hline Sites & $\mathbf{P}^{\mathrm{H}}$ & Density & $\mathbf{T}\left({ }^{\circ} \mathbf{C}\right)$ \\
\hline Norms & $\mathbf{6 , 6 - 6 , 8}$ & $\mathbf{1 , 0 2 8 - 1 , 0 3 3}$ & \\
\hline S1= Kakataré & $5,60 \pm 0,4^{\mathrm{ab}}$ & $1,025 \pm 0,0014^{\mathrm{a}}$ & $36 \pm 0,212^{\mathrm{d}}$ \\
S2= Hardé 1 & $5,18 \pm 0,32^{\mathrm{a}}$ & $1,025 \pm 0,0007^{\mathrm{a}}$ & $34,3 \pm 0,282^{\mathrm{a}}$ \\
S3= Domayo & $5,70 \pm 0,3^{\mathrm{ab}}$ & $1,025 \pm 0,0014^{\mathrm{a}}$ & $35,2 \pm 0,141^{\mathrm{bc}}$ \\
S4= Miss- & $5,80 \pm 0,2^{\mathrm{b}}$ & $1,025 \pm 0,0014^{\mathrm{a}}$ & $34,4 \pm 0,353^{\mathrm{ab}}$ \\
inguelow & & & \\
S5= Hardé 2 & $5,49 \pm 0,,^{21} \mathrm{ab}$ & $1,030 \pm 0,0021^{\mathrm{b}}$ & $35,3 \pm 0,070^{\mathrm{c}}$ \\
\hline
\end{tabular}

Table 3: Paramètres physico-chimiques du lait cru Values followed by different letters are significantly different $(\mathrm{P}<5 \%)$.

The normal $\mathrm{pH}$ of raw milk should range between 6.6 and 6.8 . However, all the milk samples analyzed (100\%) have values below 6.0 and do not respect the standards of AFNOR. It is well known that value of a sample depends on when the milk was produced by the cow, any processing done to the milk, and how long it has been packaged [23]. The samples of this study were collected in dry season. This variability in raw milk could be linked to the climate, the lactation stage, the food availability, the water intake, the health status of the cows and the milking conditions [24]. The average values of the milks analyzed are lower than those obtained by Labioui [25] in Morocco.

Average density values were lower compared to the norm, with $80 \%$ of samples of which the density is less than 1.028 . Below the density value of 1.028 , the raw milk is considered as wet [9]. In the environment of this study, this frodulous practice is used by farmers and sellers of raw milk with the aim of increasing the quantity of their product and, by extension, their income [26,27]. The density depends on the dry matter, fat content, the increase in temperature and food availability. Although it is known that water was added in our samples, It was also proved that with increasing temperature, the density and dynamic viscosity of cow milks lowered [28].

The results revealed higher average temperature values. Theses temperatures were closer to the ambient temperature during the study period Insofar as in dry season the temperature was varying from 38 to more than $42^{\circ} \mathrm{C}$. In fact, Some studies [5,29] revealed that the temperature of milk varies according to the ambient temperature with low temperatures of milk in the rainy and cold season against temperatures which can go up to $44^{\circ} \mathrm{C}$ in hot and dry season in N'Djamena in Chad. With higher temperatures, preserv- 
ing raw milk becomes difficult due to the proliferation of potentially pathogenic germs capable of altering the quality of the milk [29] and causing illness to consumers [30].

Microbiological quality of raw milk

Abundances of TMAF and Staphylococcus

The microorganism's concentration of the samples examined varied in function of different farmers (Table 4). Aerobic plate counts or TMAF ranged from $(9 \pm 0.9) 10^{3}$ (S4) to $(7.2 \pm 0.9) 10^{9}$ $\mathrm{CFU} / \mathrm{mL}$ (S3). The difference between the samples S1, S2, S4 and $\mathrm{S} 5$ was not significant but significant between all the samples and S3. About $80 \%$ of samples conforming to standards (105 CFU/ml), only site S3 has a microbial load higher than the standard. The concentration Staphylococcus ranged from $(1.2 \pm 0.3) 10^{3}$ (S4) and $(1.03 \pm 0.08) 10^{4} \mathrm{CFU} / \mathrm{mL}$ (S5). The difference was significant between all the samples analyzed. The samples in all the locations did not respected the French reference (AFNOR) range (Staphylococcus $<10^{2} \mathrm{CFU} / \mathrm{g}$ ). The concentration of Staphylococcus represents more than $13 \%$ of the TMAF in $80 \%$ of the sites.

The total aerobic mesophilic flora of the raw milk samples complies in $80 \%$ of cases with European standards $(105 \mathrm{CFU} / \mathrm{mL})$ $[31,32]$. These results are much lower than those found by other authors in several countries: in Algeria [32,33], Morocco [29], Cameroon [9]. This parameter is considered as a general indicator of the overall quality of the product because it reveals the conditions of production, more particularly hygienic practices during milking [34]. This lower bacterial contamination of the samples could be also explained by the fact that sometimes, some farmers treat sick cows themselves with the antibiotics available (at the market) and do not respect the time necessary before milking.

\begin{tabular}{|l|c|c|c|c|c|}
\hline Sites & S1 & S2 & S3 & S4 & S5 \\
\hline Tf & $(11 \pm 1,2) 10^{3 \mathrm{a}}$ & $(12,2 \pm 0,8) 10^{3 \mathrm{a}}$ & $(7,2 \pm 0,9) 10^{9 \mathrm{~b}}$ & $(9 \pm 0,9) 10^{3 \mathrm{a}}$ & $(6,4 \pm 2,1) 10^{4 \mathrm{a}}$ \\
\hline Staph & $(1,6 \pm 0,2) 10^{3 \mathrm{a}}$ & $(1,9 \pm 0,65) 10^{3 \mathrm{ab}}$ & $(2,9 \pm 1,03) 10^{3 \mathrm{~b}}$ & $(1,2 \pm 0,3) 10^{3 \mathrm{a}}$ & $(1,03 \pm 0,08) 10^{4 \mathrm{c}}$ \\
\hline
\end{tabular}

Table 4: TMAF and Staphylococcus counts Values followed by different letters are significantly different $(\mathrm{P}<5 \%)$.

\section{Staphylococcus identification}

Characteristics like morphology of the colony, Gram staining, the catalase test and the DNAse test permitted to identify 19 strains of Staphylococcus grouped into 13 strains of Staphylococcus aureus and 6 of Staphylococcus sp. (Figure1) Staphylococcus aureus was present in the samples of all the sites) with more than $50 \%$ on the site S3.

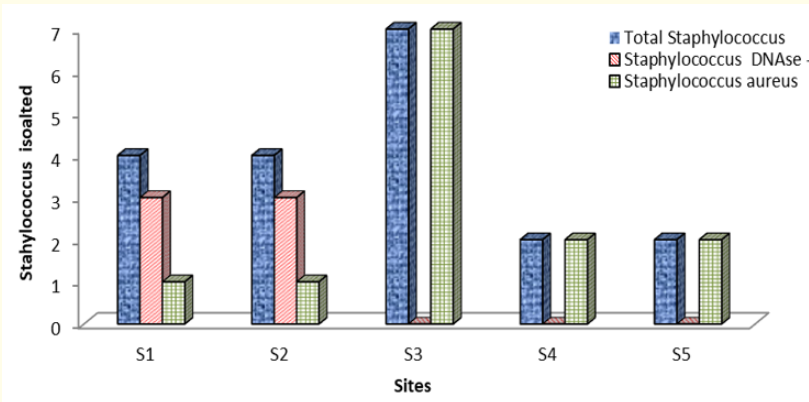

Figure 1: Repartition of different staphylococcus on the raw milks.

All the samples analyses were contaminates with Staphylococcus. I is known that Staphylococcus is a human commensal bacteria that are generally found in the nostrils, armpits, on the skin, etc.
[35,36]. Their presence in raw milk therefore reflects the non-application of hygiene rules such as washing hands [33] and mastitis in cow [32,37]. Contamination of milk becomes a major public health problem with the presence of Staphylococcus aureus as a responsible for food poisoning. This pathogenic germ constitutes a real risk for public health because it is capable, under certain conditions, of producing thermostable enterotoxins which can resist to thermal treatments [38]. The presence of Staphylococci in 100\% of our samples, with an average load of 1.7.103 CFU / $\mathrm{ml}$ is more worrying as the species $\mathrm{S}$. aureus were present in $100 \%$ of our samples compared to the $0 \%$ found by Labioui [25], 9.8\% of Yabrir [32] and $17.7 \%$ of Hamiroune [40]. The rate of the presence of S. Aureus was closer to: 70\% found by Maïworé [9]; 81.93\% found by Ghazi [33] and $100 \%$ found by Alexopoulos [39].

\section{Antibiotic resistance and percentage of resistance}

The antibiogram of the strains of Staphylococcus isolated from raw milk samples is shown in table 5 . There is $94.74 \%$ resistance to $\beta$-lactams, $78 \%$ to Macrolides, $42.1 \%$ to Glycopeptides, $15.78 \%$ to Quinolones, 5.3\% with Aminoglycosides, 10.52 with nitrofurantoin, $10.52 \%$ with fusidic acid, and $5.3 \%$ with cotrimoxazole. Levofloxacin and chloramphenicol show $100 \%$ antibacterial activity on the 19 strains of Staphylococcus isolated. The antibiogram and the resistance percentages are given in table 5 . 


\begin{tabular}{|c|c|c|c|c|c|c|c|c|c|c|c|c|c|c|c|c|c|c|c|c|}
\hline \multirow{2}{*}{ Family } & \multirow{2}{*}{ Antibiotics } & \multicolumn{19}{|c|}{ Strains } \\
\hline & & S1 & S2 & S3 & 54 & S5 & 56 & S7 & S8 & S9 & S10 & S11 & S12 & $S 13$ & S14 & S15 & S16 & S17 & S18 & S19 \\
\hline \multirow[t]{6}{*}{ Bêta-lactams } & Pénicilline G & $\mathrm{S}$ & $\mathrm{R}$ & $\mathrm{R}$ & $\mathrm{R}$ & $\mathrm{R}$ & $S$ & $\mathrm{~S}$ & $\mathrm{R}$ & $\mathrm{R}$ & $\mathrm{R}$ & $S$ & $\mathrm{R}$ & $\mathrm{R}$ & $S$ & $S$ & $S$ & $S$ & $\mathrm{R}$ & $\mathrm{R}$ \\
\hline & Oxacilline & $\mathrm{S}$ & $\mathrm{R}$ & $\mathrm{R}$ & $\mathrm{R}$ & $\mathrm{R}$ & $\mathrm{R}$ & $\mathrm{R}$ & $\mathrm{R}$ & $\mathrm{R}$ & $\mathrm{R}$ & $\mathrm{R}$ & $\mathrm{R}$ & $\mathrm{R}$ & $\mathrm{R}$ & $\mathrm{R}$ & $\mathrm{R}$ & $\mathrm{R}$ & $\mathrm{R}$ & $\mathrm{R}$ \\
\hline & Cefotaxime & $S$ & $\mathrm{R}$ & $\mathrm{R}$ & $\mathrm{R}$ & $\mathrm{R}$ & $\mathrm{R}$ & $\mathrm{R}$ & $\mathrm{R}$ & $\mathrm{R}$ & $\mathrm{R}$ & $S$ & $\mathrm{R}$ & $\mathrm{R}$ & $\mathrm{R}$ & $\mathrm{R}$ & $\mathrm{R}$ & $S$ & $\mathrm{R}$ & $\mathrm{R}$ \\
\hline & Meropenème & $S$ & $\mathrm{~S}$ & $\mathrm{R}$ & $\mathrm{S}$ & $\mathrm{R}$ & $S$ & $\mathrm{~S}$ & $S$ & $\mathrm{R}$ & $\mathrm{R}$ & $S$ & $S$ & $S$ & $S$ & $S$ & $S$ & $S$ & $\mathrm{R}$ & $S$ \\
\hline & Daptomycine & $S$ & $\mathrm{~S}$ & $\mathrm{R}$ & $\mathrm{S}$ & $\mathrm{R}$ & $S$ & $\mathrm{~S}$ & $\mathrm{R}$ & $\mathrm{R}$ & $\mathrm{R}$ & $S$ & $S$ & $S$ & $S$ & $S$ & $S$ & $S$ & $S$ & $\mathrm{R}$ \\
\hline & Moxalactam & $\mathrm{S}$ & $\mathrm{S}$ & $\mathrm{S}$ & $\mathrm{S}$ & $\mathrm{S}$ & $\mathrm{R}$ & $\mathrm{R}$ & $S$ & $\mathrm{~S}$ & $\mathrm{~S}$ & $\mathrm{~S}$ & $S$ & $S$ & $\mathrm{~S}$ & $\mathrm{~S}$ & $\mathrm{~S}$ & $\mathrm{R}$ & $S$ & $\mathrm{~S}$ \\
\hline \multirow[t]{2}{*}{ Glycopeptides } & Teicoplanine & $\mathrm{S}$ & $\mathrm{S}$ & $\mathrm{R}$ & $\mathrm{S}$ & $\mathrm{S}$ & $\mathrm{R}$ & $\mathrm{S}$ & $\mathrm{R}$ & $\mathrm{R}$ & $\mathrm{S}$ & $\mathrm{R}$ & $\mathrm{R}$ & $S$ & $\mathrm{~S}$ & $S$ & $S$ & $\mathrm{~S}$ & $\mathrm{~S}$ & $\mathrm{~S}$ \\
\hline & Vancomycine & $\mathrm{S}$ & $\mathrm{R}$ & $\mathrm{S}$ & $\mathrm{S}$ & $\mathrm{S}$ & $\mathrm{R}$ & $\mathrm{R}$ & $\mathrm{R}$ & $\mathrm{R}$ & $\mathrm{S}$ & $\mathrm{R}$ & $\mathrm{S}$ & $S$ & $\mathrm{~S}$ & $\mathrm{~S}$ & $\mathrm{~S}$ & $\mathrm{~S}$ & $\mathrm{~S}$ & $\mathrm{~S}$ \\
\hline \multirow[t]{5}{*}{ Aminosides } & Gentamycine & $\mathrm{s}$ & $\mathrm{S}$ & $\mathrm{S}$ & $\mathrm{S}$ & $S$ & $\mathrm{R}$ & $\mathrm{S}$ & $S$ & $\mathrm{~S}$ & $\mathrm{~S}$ & $S$ & $S$ & $S$ & $\mathrm{~S}$ & $\mathrm{~S}$ & $\mathrm{~S}$ & $\mathrm{~S}$ & $S$ & $S$ \\
\hline & Tobram & $\mathrm{S}$ & $\mathrm{S}$ & $S$ & $\mathrm{~S}$ & $S$ & $\mathrm{R}$ & $\mathrm{S}$ & $S$ & $S$ & $S$ & $S$ & $S$ & $S$ & $S$ & 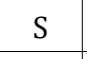 & $S$ & $S$ & $S$ & $S$ \\
\hline & Amikacine & $\mathrm{S}$ & $\mathrm{S}$ & $\mathrm{S}$ & $\mathrm{S}$ & $S$ & $\mathrm{~S}$ & $\mathrm{~S}$ & $\mathrm{~S}$ & $\mathrm{R}$ & $S$ & $\mathrm{~S}$ & $S$ & $S$ & $\mathrm{~S}$ & $\mathrm{~S}$ & $\mathrm{~S}$ & $\mathrm{~S}$ & $S$ & $\mathrm{~S}$ \\
\hline & Netilmycine & $\mathrm{S}$ & $\mathrm{S}$ & $\mathrm{S}$ & $\mathrm{S}$ & $\mathrm{S}$ & $\mathrm{R}$ & $\mathrm{S}$ & $S$ & $\mathrm{~S}$ & $\mathrm{~S}$ & $S$ & $S$ & $S$ & $\mathrm{~S}$ & $\mathrm{~S}$ & $\mathrm{~S}$ & $\mathrm{~S}$ & $\mathrm{~S}$ & $\mathrm{~S}$ \\
\hline & Isepamicine & $S$ & $\mathrm{~S}$ & $\mathrm{~S}$ & $\mathrm{~S}$ & $S$ & $\mathrm{R}$ & $\mathrm{S}$ & $S$ & $\mathrm{R}$ & $\mathrm{R}$ & $S$ & $S$ & $S$ & $S$ & 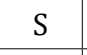 & $S$ & $S$ & S & $S$ \\
\hline \multirow{6}{*}{$\begin{array}{l}\text { Macrolides } \\
\text { and related }\end{array}$} & Erythromycine & $\mathrm{S}$ & $\mathrm{R}$ & $\mathrm{S}$ & $\mathrm{S}$ & $\mathrm{S}$ & $S$ & $\mathrm{~S}$ & $S$ & $\mathrm{R}$ & $\mathrm{S}$ & $S$ & $S$ & $S$ & $\mathrm{~S}$ & $\mathrm{~S}$ & $\mathrm{~S}$ & $\mathrm{~S}$ & $S$ & $\mathrm{~S}$ \\
\hline & Lincomycine & $\mathrm{S}$ & $\mathrm{R}$ & $\mathrm{R}$ & $\mathrm{S}$ & $\mathrm{R}$ & $\mathrm{R}$ & $\mathrm{S}$ & $S$ & $\mathrm{R}$ & $\mathrm{R}$ & $S$ & $S$ & $S$ & $S$ & 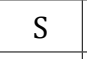 & $S$ & $S$ & $S$ & S \\
\hline & Clindamycine & $\mathrm{s}$ & $\mathrm{R}$ & $\mathrm{S}$ & $\mathrm{S}$ & $\mathrm{R}$ & $\mathrm{S}$ & $\mathrm{S}$ & $S$ & $\mathrm{R}$ & $\mathrm{I}$ & $S$ & $S$ & $S$ & $S$ & $S$ & $\mathrm{R}$ & $\mathrm{S}$ & $\mathrm{S}$ & $\mathrm{S}$ \\
\hline & Spiramycine & $\mathrm{S}$ & $\mathrm{R}$ & $\mathrm{I}$ & $\mathrm{S}$ & I & I & $\mathrm{S}$ & I & $\mathrm{I}$ & $\mathrm{S}$ & I & $\mathrm{R}$ & I & I & I & $\mathrm{S}$ & $\mathrm{S}$ & I & $\mathrm{I}$ \\
\hline & Pristinamycine & $S$ & $\mathrm{R}$ & $\mathrm{S}$ & $\mathrm{S}$ & $\mathrm{I}$ & $S$ & $\mathrm{~S}$ & $S$ & $\mathrm{R}$ & J & J & S & $S$ & J & 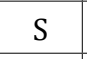 & $S$ & $S$ & S & $S$ \\
\hline & Télithromycine & S & $\mathrm{R}$ & $\mathrm{S}$ & $\mathrm{S}$ & S & S & $\mathrm{S}$ & $\mathrm{R}$ & $\mathrm{R}$ & J & S & S & S & S & S & $\pi$ & S & S & S \\
\hline \multirow{2}{*}{$\begin{array}{l}\text { Quinolones } \\
\text { and Fluoro- } \\
\text { quinolones }\end{array}$} & Ofloxacine & $\mathrm{S}$ & $\mathrm{S}$ & $\mathrm{R}$ & $\mathrm{S}$ & $\mathrm{S}$ & $\mathrm{S}$ & $\mathrm{S}$ & $\mathrm{S}$ & $\mathrm{R}$ & 3 & 3 & $\mathrm{~S}$ & $\mathrm{~S}$ & $\mathrm{~S}$ & 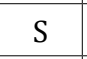 & 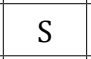 & $\mathrm{R}$ & 0 & S \\
\hline & Levofl & S & $\mathrm{S}$ & $S$ & $\mathrm{~S}$ & S & S & $\mathrm{S}$ & S & $S$ & $S$ & S & S & S & S & S & $S$ & S & S & S \\
\hline Phenicoles & $\begin{array}{l}\text { Chloramphé- } \\
\text { nicol }\end{array}$ & S & $\mathrm{S}$ & $S$ & $\mathrm{~S}$ & S & S & $\mathrm{S}$ & S & $S$ & S & S & S & $S$ & S & 3 & $S$ & S & $S$ & S \\
\hline Sulfamides & Cotrimoxazole & 3 & $\mathrm{~S}$ & 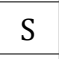 & $\mathrm{S}$ & $\mathrm{R}$ & 3 & $\mathrm{~s}$ & 3 & 3 & 3 & J & 3 & 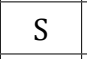 & 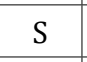 & 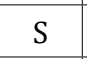 & 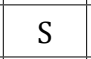 & S & 3 & $S$ \\
\hline $\begin{array}{l}\text { Nitrated } \\
\text { products }\end{array}$ & $\begin{array}{l}\text { Nitrofuran- } \\
\text { toine }\end{array}$ & S & $S$ & $S$ & $\mathrm{~S}$ & S & S & $S$ & S & $\mathrm{R}$ & S & $S$ & S & $S$ & S & S & S & $\mathrm{R}$ & S & S \\
\hline \multirow[t]{2}{*}{ Others } & Rifampicine & 5 & $\mathrm{~S}$ & $\mathrm{~s}$ & $\mathrm{~S}$ & I & $\mathrm{S}$ & $\mathrm{s}$ & 5 & $\mathrm{R}$ & $\mathrm{K}$ & 3 & $\mathrm{~s}$ & $\mathrm{~S}$ & $\mathrm{~s}$ & 3 & $\mathrm{R}$ & I & $\mathrm{S}$ & $\mathrm{s}$ \\
\hline & Acide fusidique & $\mathrm{S}$ & $\mathrm{S}$ & $\mathrm{S}$ & $\mathrm{S}$ & $S$ & $\mathrm{~S}$ & $\mathrm{~S}$ & $\mathrm{~S}$ & $\mathrm{R}$ & $\mathrm{R}$ & $\mathrm{S}$ & $\mathrm{S}$ & $\mathrm{S}$ & $\mathrm{S}$ & $\mathrm{S}$ & $\mathrm{S}$ & $\mathrm{S}$ & $\mathrm{S}$ & $\mathrm{S}$ \\
\hline
\end{tabular}

Table 5: Antibiograms of Staphylococcus strains I : intermediate ; R : Resistant ; S : Sensitive; S1-S19 : Strain 1-Strain 19

The test for the antibiotic-resistant activity of Staphylococcus isolated from our samples reveals a heterogeneous degree of resistance depending on the antibiotics used. The study revealed a higher level of resistance to $\beta$-lactams (94.74\%). This may be due to several factors: firstly, antibiotics of the $\beta$-lactam family are most used by farmers because their high availability on the informal market, their low cost and their easy administration (not requiring the presence of veterinary or health personnel) [41,42]. Secondly, on the cellular physiology, Staphylococcus produce penicillinases (enzymes which inactivate penicillin) and on the other hand they contain in their genome the mec A gene responsible for the synthesis of a protein which binds mutated penicillins (PLP2a) lacking affinity for $\beta$-lactams $[43,44]$. This result is similar to that of Abera [1], who showed $94.4 \%$ resistance of $S$. aureus to penicillin. Resistance to other families of antibiotics can be the result 
of several mechanisms [45]: modification of the structure of the antibiotic for Aminoglycosides [46], ejection of the antibiotic from the bacteria and modification of the target for Quinolones [47,48], the decrease in membrane permeability and the modification of the target for Glycopeptides [48] and the modification of the target for Macrolides [49].
Levofloxacin and chloramphenicol have shown 100\% antibacterial activity. According to Robert [45], levofloxacin has a bactericidal effect and acts by inhibiting nucleic synthesis in the bacteria, while chloramphenicol has a bacteriostatic effect by inhibiting protein synthesis in the ribosome [46]. Abera [1] in Ethiopia found similar results to ours with $100 \%$ chloramphenicol antibacterial activity against strains of $S$. aureus isolated from milk.

\begin{tabular}{|l|c|c|c|c|c|c|c|c|c|c|c|}
\hline & \multicolumn{10}{|c|}{ Antibiotics tested } \\
\hline Resistance & $\boldsymbol{\beta}$-lac. & Glyc. & Amin. & Macr. & Quin. & Chlo. & Cotr. & Nitr. & Fus. A. & Dapt. & Rifa. \\
\hline S.S & 1 & 11 & 18 & 4 & 16 & 19 & 18 & 17 & 17 & 16 & 14 \\
\hline R.S & 18 & 8 & 1 & 15 & 3 & 0 & 1 & 2 & 2 & 3 & 5 \\
\hline$\%$ R & 94,7 & 42,1 & 5,3 & 79 & 15,8 & 0 & 5,3 & 10,5 & 10,5 & 15,8 & 26,3 \\
\hline
\end{tabular}

Table 6: Resistance phenotypes of Staphylococcus isolated from milk

$\beta$-lac. : $\beta$-lactam ; Glyc.: Glycopeptides; Amin. : Aminosides ; Macr. : Macrolides ; Quin. : Quinolones ; Chlo. : Chloramphenicol ;

Cotr: Cotrimoxazole ; Nitr. : Nitrofurantoine ; Fus A.: Fusidic A. : Dapt : Daptomycin ; Rifa. : Rifampicin

S.S = Sensitive Strains ; R. S = Resistant strains; \%R = Percentage of resistance

\section{Conclusion}

The objective of this study was to identify Staphylococcus in raw milks from Maroua (Cameroon) and evaluate their resistance to antibiotics. The samples analyzed in all the sites were contaminated with Staphylococcus, especially the strain aureus. The most alarming is that these strains have a high rate of resistance to commonly used antibiotics. The concordance of our results with those of other researchers from various countries raises questions about the progress of bacterial resistance around the world. In order to ensure better quality food in the city of Maroua, Farmers should be made aware of the application of hygiene rules when milking on farms. In addition, regulation and monitoring of the administration of antibiotics to farm animals should be effective. Extending this study to other pathogenic bacteria in milk will also make it possible to assess their resistance to antibiotics.

\section{Conflict of Interest}

The authors declare that there is no conflict of interest relating to this manuscript.

\section{Bibliography}

1. Abera MB., et al. "Isolation and identification of Staphylococcus aureus from bovine mastitic milk and their drug resistance patterns in Adama town, Ethiopia”. Journal of Veterinary Medicine and Animal Health 2.3 (2010): 29-34.
2. Mami A. "Recherche des bactéries lactiques productrices de bactériocines à large spectre d'action vis-à-vis des germes impliqués dans les toxi-infections alimentaires en Algérie". Thèse de Doctorat Université d'Oran (2013): 1-157

3. FAO. "Food and Agriculture Organization of the United Nations)". In: Muehlhoff E, Bennett A, McMahon D. Milk and Dairy Products in Human Nutrition. Rome, Italy (2013).

4. Beldjilali AF. “Contribution à l'étude microbiologique et sanitaire du lait cru de brebis de la région Ouest de l'Algérie". Thèse de doctorat, Université d'Oran 1 (2015): 1-164.

5. Koussou MO., et al. "Evaluation de la qualité physico-chimique et hygiénique du lait de brousse et des produits laitiers locaux commercialisés dans les bars laitiers de N'Djamena au Tchad". Revue Marocaine des Sciences Agronomiques et Vétérinaires 60.4 (2007): 45-49.

6. Oliver SP., et al. "Food safety hazards associated with consumption of raw milk". Foodborne Pathogens and Diseases 6.7 (2009): 793-806.

7. M'Sadak Y and I Hamed. “Évolution de la qualité cellulaire du lait de vache: Description et facteurs de variation chez deux grands troupeaux soumis à la traite tri-quotidienne (Sahel Tunisien)". Revue Marocaine des Sciences Agronomiques et Vétérinaires 4.2 (2016): 60-69. 
8. Bradely AJ. "Bovine mastitis an evolving disease". Veterinary Journal 164 (2002): 116-128.

9. Maïworé J., et al. "Influence des conditions de la traite sur les qualités physico-chimiques et microbiologiques du lait cru collecte à Maroua, Cameroun" Afrique Science 14.4 (2018): 235-248.

10. Burtin H., et al. "Sécurité sanitaire des aliments". Ensaia, Université de Lauraine (2014): 1-55.

11. Kongo JM., et al. "Monitoring and identification of bacteria associated with safety concerns in the manufacture of São Jorge, a Portuguese traditional cheese from raw cow's milk". Journal of Food Protection 71.5 (2008):986-992.

12. Maïworé J., et al. "Qualité microbiologique et physico-chimique des laits fermentés consommés à Maroua (Cameroun)". International Journal of Biological Chemistry Sciences 12. 3 (2018) :1234-1246.

13. Dufour B., et al. "La sécurité microbiologique: implication $\mathrm{du}$ lait et des produits laitiers dans les maladies infectieuses d'origine alimentaire". In: La sécurité des produits laitiers, 5ème conférence européenne d'Arilait, Paris Recherches (2005) :13-21.

14. Robert D. "Staphylococcus aureus résistant à la méticilline (SARM): généralités, antibiotiques actifs, résistances acquises, et implication en pathologie communautaire illustrée par l'exemple des infections acquises au cours de la pratique sportive". Thèse de Doctorat, Université d'Angers (2013): 1-126.

15. Lowy FD. "Antimicrobial resistance: the example of Staphylococcus aureus". The Journal of Clinical Investigation 111. 9 (2003).

16. De Billerbeck VG. "Huiles essentielles et bactéries résistantes aux antibiotiques”. Phytothérapie 5 (2007): 249-253.

17. Abdelatif B. "Contribution à l'évaluation de la qualité physico-chimique et bactériologique de lait cru et diagnostique de brucellose et mammites dans la région de Tlemcen en Algérie". Mémoire d'ingénieur, Université Abou Bekr Belkaid d'Algérie (2010): 80.

18. Beerns H and FM Luquet. "Guide pratique d'analyse microbiologique des laits et des produits laitiers", Ed. Lavoisier, Paris (1987).

19. NF V08-051 "Microbiologie des aliments Dénombrement des microorganismes par comptage des colonies obtenues à $30^{\circ} \mathrm{C}$. Méthode de routine (1999): 8.
20. Kateete DP., et al. "Identification of Staphylococcus aureus: DNase and Mannitol salt agar improve the efficiency of the tube coagulase test". Annals of Clinical Microbiology and Antimicrobials 9 (2010): 23.

21. Eucast: European Committee for Antimicrobial Susceptibility Testing "Dermination of minimum inhibitory concentration (MCIs) of antibacterial agents by agar dilution". Clinical Microbiology and Infection 6 (2017): 509-515.

22. Reller LB., et al. "Antimicrobial Susceptibility Testing": A Review of General Principles and Contemporary Practices". Clinical Infectious Diseases 49 (2009): 1749-1755.

23. Helmenstine, A. M. "What Is the Acidity or pH of Milk?" Thought Co 11 (2020).

24. Vignola CL. "Science et technologie du lait, Transformation du lait". Edition Presses internationales polytechniques 2 (2010) 532.

25. Labioui H., et al. "Etude physico-chimique et microbiologique des laits crus". Bulletin de la Société de pharmacie de Bordeaux 148 (2009): 7-16.

26. Cuq JL. "Microbiologie Alimentaire" Université de Montpellier II, Ed. Sciences et Techniques du Languedoc Montpellier (2007).

27. Kouame SM., et al. "Analyse des risques microbiens du lait cru local à Abidjan (Côte d'Ivoire)" Revue Africaine de Santé et de Productions Animales 8 (2010): 35-42.

28. Kumbár V and Š Nedomová. "Viscosity and analytical differences between raw milk and UHT milk of Czech cows". Scientia Agriculturae Bohemica 4 .2 (2015): 78-83.

29. Ouazzani N., et al. "Evaluation de la qualité microbiologique du lait cru dans la région du Gharb, Maroc". International Journal of Innovation and Scientific Research 9.2 (2014): 487-493.

30. Kaouche-Adjilane and S Mati. "Effets des pratiques d'élevage sur la variation de la A.qualité hygiénique et nutritionnelle du lait cru dans la région médio-septentrionale en Algérie". Revue de Medecine Veterinaire 168.7-9 (2017): 151-163.

31. Afif $M$ and Faid MN. "Qualité microbiologique du lait cru produit dans la région de Tadla au Maroc". Reviews in Biology and Biotechnology 7.1 (2008): 2-7.

32. Yabrir B., et al. "Qualité microbiologique du lait cru ovin collecte dans la steppe centrale de l'Algérie". Afrique Science 9.2 (2013): 86-92. 
33. Ghazi K and A Niar. "Qualité hygiénique du lait cru de vache dans les différents élevages de la Wilaya de Tiaret (Algérie)". Tropicultura 29 (2011) :193-196.

34. Baazize-Ammi D., et al. "Qualité bactériologique et sanitaire du lait cru de bovins des circuits direct et indirect dans la région centre de l'Algérie". Annual Review of Marine Science Agron Remedies Veterinary 7.2 (2019): 267-272.

35. Even S., et al. "Staphylococcus aureus virulence expression is impaired by Lactococcus lactis in mixed cultures" Applied and Environmental Microbiology 75.13 (2009): 4459-4472.

36. Benhamed BN Université d'Oran. "Evaluation de la qualité microbiologique et sanitaire du lait cru dans la région d'Oran (Algérie)". Thèse unique, Faculté des Sciences de la Nature et de la Vie, Département de Biologie (2014) 141.

37. Contreras A., et al. "Mastitis in small ruminants" Small Ruminant Research 68 (2007):145-153.

38. Ashnafi M. "Effect of container smoking and incubation temperature on the microbiological and ergo a traditional Ethiopian sour milk". International Dairy Journal 6 (1996): 94.

39. Hamiroune M., et al. "Qualité bactériologique du lait cru de vaches locales et améliorées vendu dans les régions de Jijel et de Blida (Algérie) et impact sur la santé publique". Annales de médecine vétérinaire 158 (2014):137-144.

40. Alexopoulos A., et al. "Microbiological quality and related factors of sheep milk produced of NE Greece". Anaerobe 17.6 (2011): 276-279.

41. Fedama WM and L Kinserbe. "Etude de quelques mécanismes de résistance aux antibiotiques des bactéries isolées de viande de bœuf vendue dans les abattoirs et quelques points de vente de la ville de Maroua". Mémoire de DIPES II". Ecole Normale Supérieure/Université de Maroua (2017): 1-47.

42. Gay E., et al. "Utilisation des antibiotiques chez les ruminants domestiques en France: résultats d'enquêtes de pratiques auprès d'éleveurs et de vétérinaires". Anses, Laboratoire de Lyon, France (2012): 8-11.

43. Guerin-Faublee V. "Les mécanismes de résistance des bactéries aux antibiotiques" In: Journées Nationales GTV, Lille (2010): 93-101.

44. Scott G. "Antibiotic resistance". Medicine (Baltimore) 37 (2009): 551-556.
45. Robert D. "Staphylococcus aureus résistant à la méticilline (SARM): généralités, antibiotiques actifs, résistances acquises, et implication en pathologie communautaire illustrée par l'exemple des infections acquises au cours de la pratique sportive" Thèse de Doctorat en pharmacie, Université d'Angers (2013): 1-114.

46. Dorosz Ph. et al. "Guide pratique des médicaments". 30e éd. Maloine Paris (2011): 1892.

47. DeMarco CE., et al. "Efflux-related resistance to norfloxacin, dyes, and biocides in bloodstream isolates of Staphylococcus aureus" Antimicrob Agents Chemother 51 (2007): 3235-3239.

48. Lowry FD. "Antimicrobial resistance: the example of Staphylococcus aureus". Journal of Clinical Investigation 111 (2003) :1265-1273.

49. Onerba: Observatoire National de l'Epidémiologie de la Résistance Bactérienne aux Antibiotiques. "Rapport d'activité" Vivactis Plus Ed (2011).

\section{Assets from publication with us}

- Prompt Acknowledgement after receiving the article

- Thorough Double blinded peer review

- Rapid Publication

- Issue of Publication Certificate

- High visibility of your Published work

Website: https://www.actascientific.com/

Submit Article: https://www.actascientific.com/submission.php

Email us: editor@actascientific.com

Contact uS: +919182824667 